\title{
Contrast-to-noise ratios of different dental restorative materials: An in-vitro cone beam computed tomography study
}

\section{Purpose}

In radiological views, strong beam hardening and streaking artifacts occur due to high-density structures and polyenergetic X-ray beams, and these lead to misdiagnosis. This study was performed in vitro to compare the contrast-to-noise ratio (CNR) of commonly used dental restorative materials by using Cone Beam Computed Tomography (CBCT) images with and without artifact reduction (AR) mode.

\section{Materials and Methods}

A total of 108 molar teeth were restored with nine different groups of restorative materials, with each group containing 12 teeth. Teeth were placed in a dry human mandible and scanned, one by one, via Planmeca 3D ProMax (Planmeca, Helsinki, Finland) with and without AR mode. Images were analyzed using ImageJ software (National Institutes of Health, Bethesda, MD) to calculate the CNR.

\section{Results}

CNR was calculated to be the highest in compomer (Glassiosite) images without AR mode (mean: 3.36) and with AR mode (mean: 3.61). CNR was calculated to be the lowest in amalgam (Tytin) images without AR mode (mean: 0.21 ) and with AR mode (mean: 0.23). A significant difference was found between materials in terms of CNR measurements ( $\leq 0.05)$. CNR measurements were increased after the AR mode application $(p \leq 0.05)$.

\section{Conclusion}

AR mode was effective in reducing artifacts arising from dental materials on CBCT images, so it is necessary to use AR mode for correct diagnoses.

Keywords: Cone-Beam Computed Tomography; contrast-to-noise ratio; dental materials; artifacts; image quality

\section{Introduction}

Cone Beam Computed Tomography (CBCT) has been used in dentistry for dental, maxillofacial, and various head and neck examinations (1). This technology supplies 3D images for regions of interest with high spatial resolution, geometric accuracy, and lower ionizing radiation doses than other tomographic devices $(2,3)$. Many parameters affect image quality; these include the field of view (FOV), X-ray beam quality and quantity, voxel sizeand rotation arc in CBCT images (4).

Imaging technology should obtain high-quality images with sufficient contrast-to-noise ratio (CNR) and soft-tissue differentiation while minimizing the required dose of radiation (5).

Since CNR is considered a standard factor in the evaluation of image quality, it has been measured in previous studies. Researchers have stated that the same material exhibits different CNR values with different exposure parameters $(6,7)$.

\author{
Seval Bayrak' ${ }^{1}$, \\ Emine Sebnem \\ Kursun-Cakmak ${ }^{2}$, \\ Hakan Kamalak ${ }^{3}$
}

ORCIDIDs of the authors: S. B. 0000-0003-0819-4547; E.S.K.C. 0000-0002-7113-5450; H.K. 0000-0002-1497-2009

${ }^{1}$ Abant Izzet Baysal University, Dentistry Faculty, Dentomaxillofacial Radiology Department, Bolu, Turkey

${ }^{2}$ Ministry of Health, Türkiye Public Hospitals Agency, Ankara, Turkey

${ }^{3}$ Kahramanmaraş Sütçü Imam University, Dentistry Faculty, Department of Restorative Dentistry, Kahramanmaraş, Turkey

Corresponding Author: Seval Bayrak

E-mail: dtseval@hotmail.com

Received: 28 November, 2018 Revised: 21 December, 2018 Accepted: 28 May, 2019

DOI: 10.26650/eor.20200079 
CBCT manufacturers are developing artifact reduction (AR) software to decrease the influence of beam hardening and streaking artifacts caused by high-density materials; this result in an increased CNR value $(8,9)$. Although these types of software programs eliminate streaks far from metallic objects, the details around metal-tissue interfaces, which might be the main regions of interest, still may not be visible to clinicians (10).

As a result of dental materials having been developed very rapidly, many studies have been planned to analyze their biological, physical, and mechanical characteristics, all of which can affect and predict their performance. Knowledge of the characteristic properties of dental materials is essential to support their correct application and to expect the long-term performance of these materials (11).

Materials containing metal have been reported to cause artifacts that inhibit the diagnostic quality of CBCT images by decreasing contrast, concealing structures, and consequently impairing estimates of the region of interest. In radiographic images, beam hardening and streaking effects occur due to high-density structures and polyenergetic X-ray beams; these lead to dark streaks that are known as image artifacts, resulting in misdiagnosis (12). The intensity of these artifacts increases in CBCT images as the percentage of radio-opacifying materials increases (13).

This study aimed to compare in-vitro the CNR of commonly used dental restorative materials by using $C B C T$ images with and without AR mode.

\section{Materials and Methods}

\section{Preparation of teeth}

This in vitro study protocol was in accordance with the Declaration of Helsinki approved by the Local Ethical Committee of Firat University (Review No. 15.06.17/02).

108 noncavitated human permanent molar teeth extracted for periodontal or orthodontic reasons independent from this study were used. The teeth had no cavitations, restorations, or hypoplastic pits as judged by the naked eye. Extracted teeth were cleaned and kept in distilled water for 24 hours at $37^{\circ} \mathrm{C}$.

Class I (occlusal) cavities ( $7 \mathrm{~mm} \times 3 \mathrm{~mm} \times 4 \mathrm{~mm}$ ) were made with a carbide bur (\#330, Mani; MANI Inc., Tokyo, Japan) for 108 molar teeth and randomly divided into nine groups each containing 12 teeth.

After cavity preparation, the groups were restored with 9 different restorative materials. These materials are summarized with their specifications in Table 1.

\section{CBCT imaging}

A dry human mandible covered with a pink wax layer to simulate soft tissues was used in the imaging procedures, and the restored teeth were placed in the same socket throughout the study. A hexagonal plexiglass box filled with

Table 1. Restorative materials and their characteristics evaluated in the study

\begin{tabular}{|c|c|c|c|c|c|}
\hline Material Name & Manufacturer & Material type & Matrix type & Filler content & $\begin{array}{c}\text { Filler ratio } \\
\%\end{array}$ \\
\hline $\begin{array}{c}\text { Estelıte }^{\oplus} \text { Sıgma } \\
\text { Quıck }\end{array}$ & $\begin{array}{c}\text { Tokuyama Tokyo, } \\
\text { Japan }\end{array}$ & $\begin{array}{l}\text { Submicron filled } \\
\text { composite resin }\end{array}$ & Bis-GMA, TEGDMA & $\begin{array}{l}\text { Spherical silica-zirconia } \\
\text { filler and silica-zirconia } \\
\text { prepolymerized fillers }\end{array}$ & 82 \\
\hline $\begin{array}{l}\text { Estelıte }^{\circledast} \text { Flow } \\
\text { Quıck }\end{array}$ & $\begin{array}{c}\text { Tokuyama Tokyo, } \\
\text { Japan }\end{array}$ & $\begin{array}{l}\text { Low viscosity, medium } \\
\text { flow, light cured, } \\
\text { radiopaque composite } \\
\text { resin }\end{array}$ & $\begin{array}{c}\text { Bisphenol A polyethoxy } \\
\text { Methacrylate (Bis-MPEPP), } \\
\text { TEGDMA, } \\
\text { UDMA }\end{array}$ & $\begin{array}{l}\text { Silica- zirconia filler and } \\
\text { silica-titanium filler }\end{array}$ & 71 \\
\hline Filtek Bulk Fill & $\begin{array}{c}\text { 3M-Espe } \\
\text { (St. Paul, Mn, USA) }\end{array}$ & $\begin{array}{l}\text { Bulk-fill flowable } \\
\text { composite }\end{array}$ & Bis-GMA, UDMA Bis-EMA & Procrylat resins & 64.5 \\
\hline Surefil SDR & $\begin{array}{l}\text { Dentsply Caulk, } \\
\text { Universal }\end{array}$ & Bulk-fill composite & $\begin{array}{c}\text { Modified UDMA TEGDMA, } \\
\text { EBPDMA }\end{array}$ & $\begin{array}{l}\text { Ba-Al-F-B-Si glass and St- } \\
\text { Al-F-Si glass as fillers }\end{array}$ & 68 \\
\hline lonoseal & $\begin{array}{l}\text { VOCO Gmbh, } \\
\text { Cuxhaven, } \\
\text { Germany }\end{array}$ & $\begin{array}{l}\text { Resin-reinforced glass } \\
\text { ionomer cement }\end{array}$ & $\begin{array}{c}\text { Bis-GMA, HEMA, } \\
\text { TEDMA }\end{array}$ & $\begin{array}{l}\text { Fluoroaluminum silicate, } \\
\text { champherechinon, amine }\end{array}$ & - \\
\hline Tytin & $\begin{array}{c}\text { Kerr } \\
\text { Manufacturing Co., } \\
\text { Romulus, MI, USA }\end{array}$ & $\begin{array}{l}\text { Spherical high-copper } \\
\text { amalgam alloy }\end{array}$ & - & $\begin{array}{c}\text { Silver } 59 \%, \text { Tin } 28 \%, \\
\text { Copper } \% 13, \operatorname{Hg} 42.5 \%\end{array}$ & - \\
\hline GCP Glass Fill & $\begin{array}{l}\text { Gcp Dental } \\
\text { Elmshorn } \\
\text { Germany }\end{array}$ & $\begin{array}{l}\text { New carbomised nano- } \\
\text { particles }\end{array}$ & Modified Polysiloxanes & $\begin{array}{l}\text { Fluoro-aluminosilicate } \\
\text { Glass, Apatite, Polyacids }\end{array}$ & - \\
\hline $\begin{array}{l}\text { CAD/CAM } \\
\text { Katana }\end{array}$ & $\begin{array}{l}\text { KATANA }^{\oplus} \text { Noritake } \\
\text { Dental Supply } \\
\text { Japan }\end{array}$ & $\begin{array}{l}\text { CAD/CAM inlay } \\
\text { restorations }\end{array}$ & - & - & - \\
\hline Glassiosite & $\begin{array}{l}\text { VOCO Gmbh } \\
\text { Cuxhaven, } \\
\text { Germany }\end{array}$ & Compomer & $\begin{array}{c}\text { BisGMA, di- } \\
\text { UDMA,TEGDMA, BHT }\end{array}$ & Glass ceramics, silicates & 77.5 \\
\hline
\end{tabular}




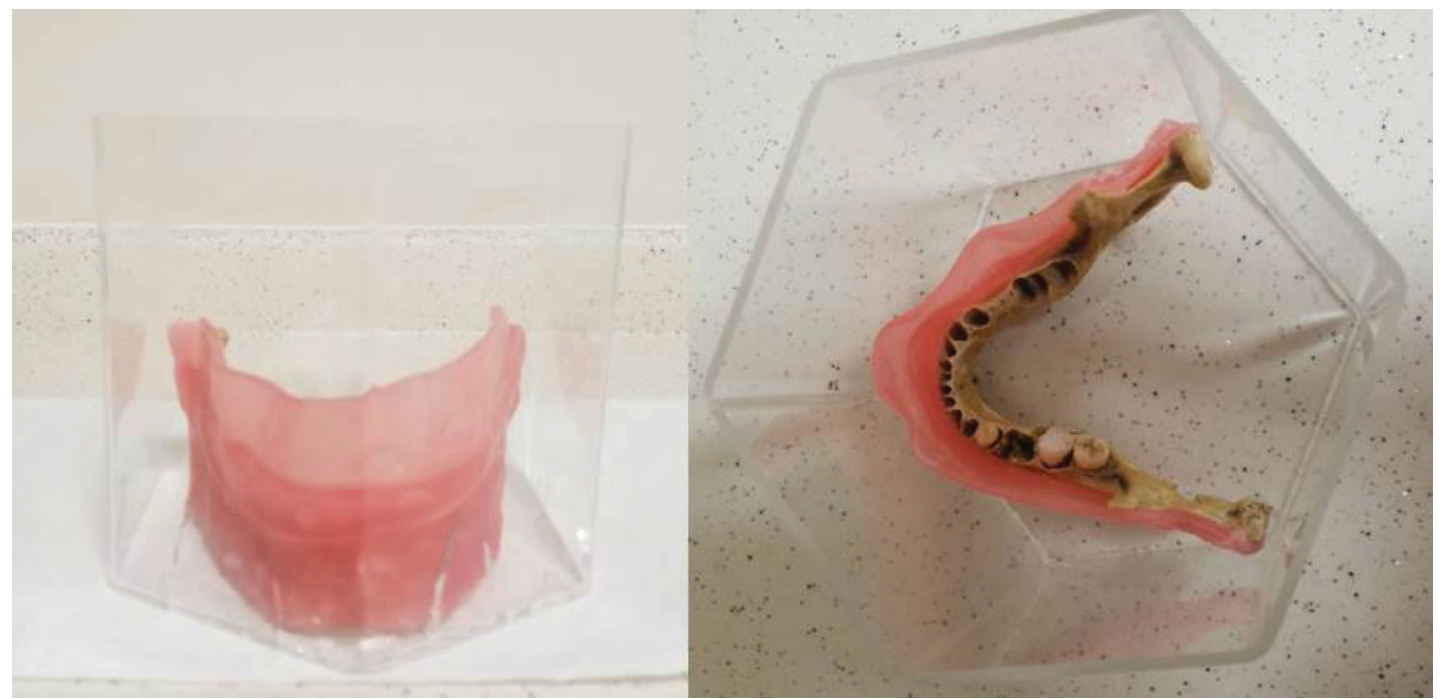

Figure 1. Dry human mandible positioned in a hexagonal plexiglass box with soft base plate wax covering the mandibular crest.

water to mimic clinical conditions was used to position the machine. Colored markers were made to place the mandible into the same position after changing the teeth (Figure 1).

The mandible was radiographed with a Planmeca 3D ProMax (Planmeca, Helsinki, Finland). This device was operated with and without $A R$ mode parameters at $76 \mathrm{kVp}, 4.5 \mathrm{~mA}$, $13.5 \mathrm{sn}, 20 \times 10.2 \mathrm{~cm}$ FOV, and $0.4 \mathrm{~mm}$ voxel size.

For each of the restorative materials, the mandible was scanned 24 times ( 12 times with the AR option and 12 times without the AR option) after changing the restored teeth ( $\mathrm{n}$ $=12$ ). A total of 216 scans were acquired for the nine different restorative materials.

All images were evaluated by one maxillofacial radiologist on two separate sessions with at least a one-week interval.

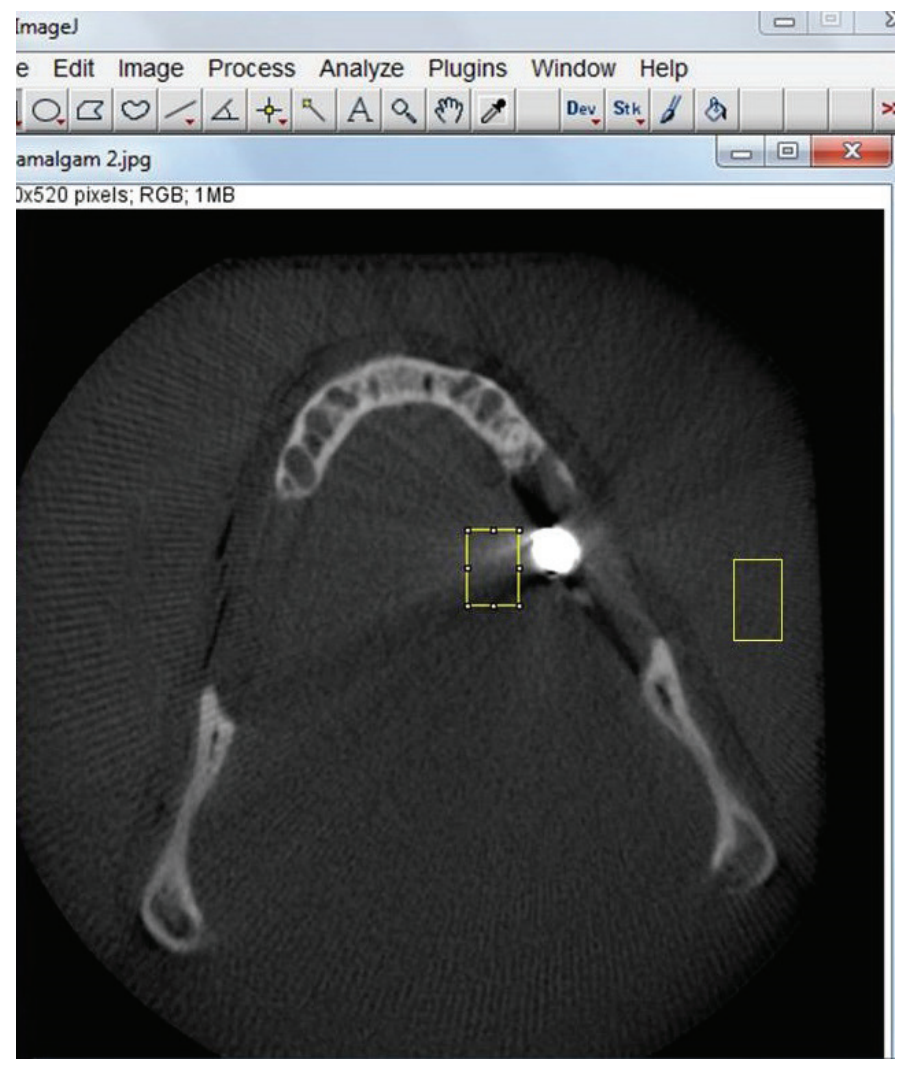

Figure 2. Areas of interest used for CNR calculation.

\section{CNR measurement}

Volumes were exported using multislice DICOM format. Identical images were chosen at the same level from each restored tooth image, and measurements were made using ImageJ software (National Institutes of Health, Bethesda, MD). Two separate areas were selected for each image, and mean gray value and standard deviation were measured. The first area was selected on the wax located lingual to the dental restorative material; the second area, called the control area, was chosen where the artifact was minimal (Figure 2). The CNR was calculated using the following formula: (9)

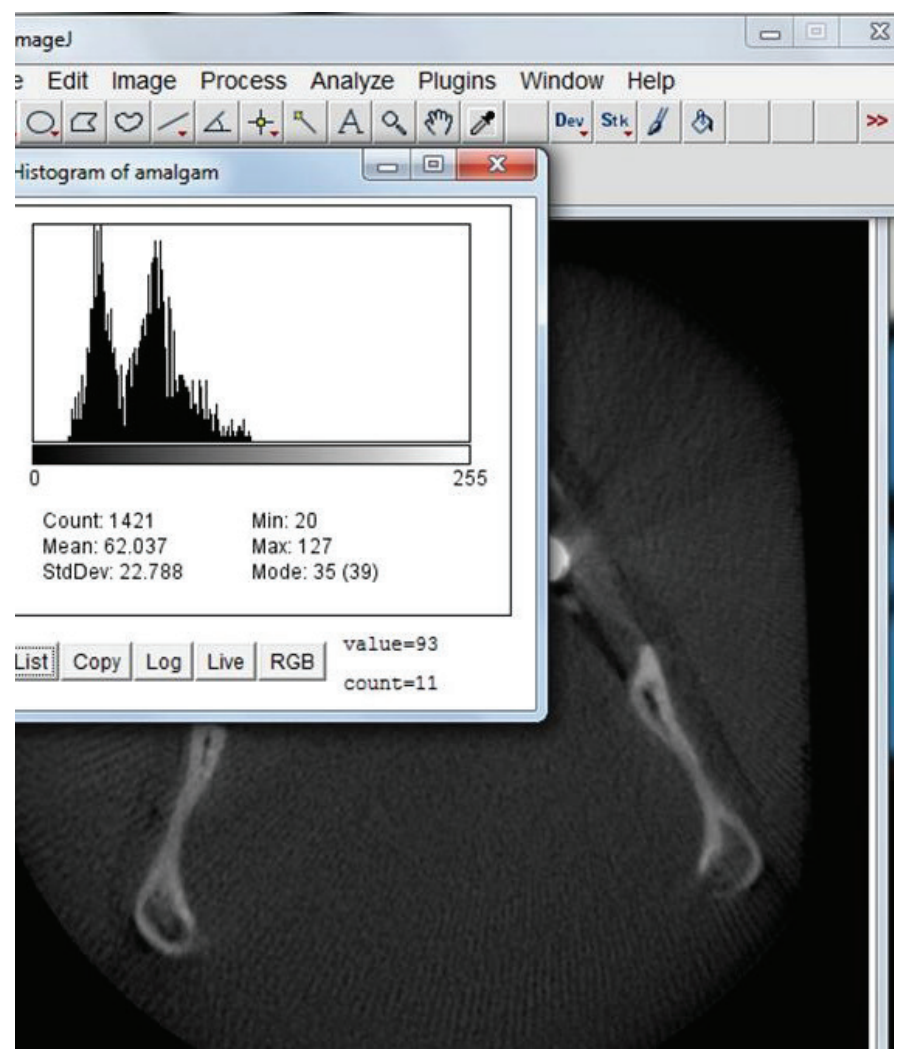

Figure 3. Histogram showing CNR values of restorative materials. 
Table 2. Contrast-to-noise ratio (CNR) measurement values with and without AR mode for various restorative materials

\begin{tabular}{|c|c|c|c|c|c|c|c|c|c|c|c|}
\hline \multirow[b]{2}{*}{ Materials } & \multirow[b]{2}{*}{$\mathbf{N}$} & \multicolumn{4}{|c|}{ Without AR Module } & \multirow[b]{2}{*}{$\mathbf{P *}$} & \multicolumn{4}{|c|}{ With AR Module } & \multirow[b]{2}{*}{ P* } \\
\hline & & Mean & SD & Median & $\begin{array}{c}\text { Range } \\
\text { (min-max) }\end{array}$ & & Mean & SD & Median & $\begin{array}{c}\text { Range } \\
\text { (min-max) }\end{array}$ & \\
\hline Gcp Glass Fill & \multirow{9}{*}{12} & $0.49^{\mathrm{a}}$ & 0.07 & 0.51 & $0.30-0.57$ & \multirow{9}{*}{0.001} & $0.52^{\mathrm{a}}$ & 0.08 & 0.55 & $0.31-0.61$ & \multirow{9}{*}{0.001} \\
\hline lonoseal & & $0.58^{\mathrm{a}}$ & 0.12 & 0.57 & $0.42-0.92$ & & $0.62^{\mathrm{a}}$ & 0.13 & 0.59 & $0.49-0.98$ & \\
\hline Estelite Sigma Quick & & $1.29^{b}$ & 0.17 & 1.25 & $1.13-1.65$ & & $1.44^{\mathrm{b}}$ & 0.20 & 1.37 & $1.25-1.84$ & \\
\hline Cad-Cam/Katana & & $0.25^{\mathrm{a}}$ & 0.50 & 0.25 & $0.19-0.37$ & & $0.29^{\mathrm{a}}$ & 0.07 & 0.27 & $0.21-0.49$ & \\
\hline Tytin & & $0.21^{\mathrm{a}}$ & 0.03 & 0.22 & $0.14-0.27$ & & $0.23^{\mathrm{a}}$ & 0.03 & 0.24 & $0.16-0.29$ & \\
\hline Estelite Flow Quick & & $2.30^{c}$ & 0.25 & 2.20 & $1.92-2.69$ & & $2.47^{c}$ & 0.23 & 2.42 & $2.11-2.84$ & \\
\hline Filtek Bulk Fill & & $3.04^{d}$ & 0.39 & 2.97 & $2.40-3.69$ & & $3.20^{d}$ & 0.43 & 3.10 & $2.51-2.89$ & \\
\hline Glassiosite & & $3.36^{d}$ & 0.12 & 3.36 & $3.14-3.64$ & & $3.61^{d}$ & 0.15 & 3.59 & $3.28-3.90$ & \\
\hline Surefil SDR & & $2.41^{c}$ & 0.44 & 2.46 & $1.24-2.85$ & & $2.57^{c}$ & 0.47 & 2.64 & $1.32-3.10$ & \\
\hline
\end{tabular}

*P-values refer to statistically significant differences between groups $(p<0.05)$. SD: Standard Deviation

$$
\mathrm{CNR}=\frac{\mid \text { Mean }_{\text {wax }}-\text { Mean }_{\text {control }} \mid}{\sqrt{S D_{\text {wax }}^{2}+S D_{\text {control }}^{2}}}
$$

Where mean is the mean gray value and SD is the standard deviation gray value in the same region of interest as seen in Figure 3.

\section{Statistical analysis}

A non-parametric test (Kruskal-Wallis Test) was used due to unequal variances across groups, and another non-parametric test (the Mann-Whitney $U$ test) was performed for comparisons between groups. The SPSS 10.0@ software (SPSS Inc., IBM Company Headquarters, Chicago, IL) was used for analyzing data. The significance level value was set at 0.05 .

\section{Results}

The compomer (Glassiosite) exhibited the highest CNR (mean: 3.36), and amalgam (Tytin) exhibited the lowest CNR (mean: 0.21), showed statistically significant difference without AR mode ( $p \leq 0.05$, Table 2 ).

The compomer (Glassiosite) exhibited the highest CNR (mean: 3.61), and amalgam (Tytin) exhibited the lowest CNR (mean: 0.23), showed statistically significant difference with AR mode ( $p \leq 0.05$, Table 2 ).

When we compared CNR using the AR module, significant differences were found between groups ( $p \leq 0.05$ ). The AR application enhanced the CNR values of all the tested materials.

\section{Discussion}

Contrast resolution, which is identified as the capability to discriminate between different contrast levels in an acquired image, is a substantial aspect of image quality in CBCT scans (14). The CNR is a factor associated with image quality rather than image noise. It is one factor among many other factors that depend on an acceptable level of lesion-to-background contrast $(15,16)$.
In the present study, AR mode indicated positive effects on CBCT images of dental restorative materials with a significant increase of CNR results. Applying the AR algorithm to CBCT scans prolongs the reconstruction time; therefore, when high-density materials are in the FOV, applying the AR algorithm is indicated to increase the image quality (6).

Bechara et al. (17) showed that the CNR is increased if the AR algorithm is used, but metal artifacts cause a decrease in the CNR. Previous studies report that artifacts and low CNR, particularly in the presence of gutta percha and canal sealers, lead to misdiagnoses of root fractures and voids and also lead to false-positive diagnoses (9).

In studies conducted with a Planmeca ProMax CBCT system, Kamburoğlu et al. (18) estimated no difference in the examination of peri-implant and periodontal defects among CBCT scans with and without the AR mode. Bechara et al. (12) found the highest accuracy of detecting root fractures in endodontically treated teeth without the AR mode.

It has been stated that using AR modes may be helpful if there is no need for high contrast and spatial resolution. This was stated as a result of a study that proved that the accuracy of root fracture detection in endodontically treated teeth was reduced after using the AR modes in two different CBCT devices (9).

Demirtürk et al. (9) investigated the CNR of multiple exposure parameters for different types of retrograde filling materials in CBCT scans with and without AR mode and stated that although there was no statistically significant difference between Biodentine, SuperEBA, MTA, and amalgam, the highest CNR was seen in Biodentine. Also, they reported that AR mode reduced the effect of the beam hardening and streaking artifacts caused by filling materials, resulting in a significant increase in the CNR seen with all four root-end filling materials (9).

Querioz et al. (6) studied the efficacy of AR mode in different dental materials and observed a significant reduction of artifact expression in tested materials except for gutta-percha, which may be explained by its having a low number of atoms. Parsa et al. (19) investigated if the AR tool can increase the gray value levels in CBCT images which were obtained 
after implant placement and reported that the software did not correct the voxel gray values caused by the metal artifact around the implant in dry human mandibles.

Pauwels et al. (20) stated that CNR values are dependent on specific machines due to variations in hardware and software. This study was designed with a single CBCT with single exposure settings. Therefore, these results cannot be compared with those obtained from other CBCT units. Future studies will focus on other CBCT units and several exposure settings.

We recommend that $C B C T$ imaging of patients with high-density dental materials be obtained using AR mode. In this way, the diagnostic quality is protected with an increase in CNR values. In examinations of CBCT images obtained for various reasons, it should be borne in mind that pathological conditions, such as caries, fracture, resorption, and other conditions, can be overlooked near restorations with lower CNR values, so it is better to support the diagnosis with an additional imaging modality (15).

\section{Conclusions}

Within the limitations of this study, we conclude that the CNR is affected by different restorative materials in CBCT scans. High-density materials exhibited lower results, and the application of the AR algorithm enhanced the CNR values. AR can be used on CBCT images of objects containing high-density restorative materials due to its efficacy in enhancing image quality.

Türkçe Öz: Farklı dental restoratif materyallerin kontrast noise oranı: bir in- vitro konik işınlı bilgisayarlı tomografi çalışması. Amaç: Radyografik görüntülerde, kuvvetli ışın sertleşmesi ve saçılma artefaktları yüksek dansiteli yapılardan ve polienerjik $X$ ışını demetinden kaynaklanır ve yanlış tanıya neden olur. Bu çalışma yaygın kullanılan dental restoratif materyallerin in vitro olarak Konik Işınlı Bilgisayarlı Tomografi (KIBT) görüntülerinde artefakt azaltma (AA) modu kullanılarak ve kullanılmadan kontrast noise oranını (KNO) kıyaslamak için yapıldı. Materyal ve Metod: Her biri 12 dişten oluşan toplamda 108 molar diş dokuz farklı grup restoratif materyalle restore edildi. Dişlerin her biri kuru insan mandibulasına yerleştirilerek $A A$ modu kullanılarak ve kullanılmadan Planmeca 3D ProMax(Planmeca, Helsinki, Finland) ile tarandı. Görüntüler ImageJ (National Institutes of Health, Bethesda) programı kullanılarak analiz edilip KNO hesaplandı. Bulgular: KNO, AA modu kullanılmadan (ortalama: 3,36) ve AA modu kullanılarak (ortalama:3,61) en yüksek kompomer (Glassiosite) görüntülerinde; $A A$ modu kullanılmadan (ortalama: 0,21 ) ve $A A$ modu kullanilarak (ortalama:0,23) en düşük amalgam (Tytin) görüntülerinde hesaplandı ( $p \leq 0.05$ ). KNO ölçümleri $A A$ modu kullanıldığında artış gösterdi. ( $p \leq 0.05)$. Sonuç: $A A$ modu KIBT görüntülerinde dental materyallerden kaynaklanan artefaktları azaltmada etkilidir ve AA modunu kullanmak doğru tanı için gereklidir. Anahtar Kelimeler: Konik ışılı bilgisayarlı tomografi; kontrast noise oranı; dental materyal; artefakt; imaj kalitesi

Ethics Committee Approval: This in vitro study protocol was in accordance with the Declaration of Helsinki and the study protocol was approved by the Local Ethical Committee of Firat University (Review No. 15.06.17/02).

Informed Consent: The informed consents were provided by the participants.

Peer-review: Externally peer-reviewed.

Author contributions: ESKC designed the study. ESKC and HK participated in generating the data for the study. SB participated in gathering the data for the study. ESKC participated in the analysis of the data. SB wrote the majority of the original draft of the paper. SB and ESKC participated in writing the paper. All authors approved the final version of this paper.

Conflict of Interest: The authors had no conflict of interest to declare.

Financial Disclosure: The authors declared that this study has received no financial support.

\section{References}

1. Scarfe WC, Li Z, Aboelmaaty W, Scott SA, Farman AG. Maxillofacial cone beam computed tomography: essence, elements and steps to interpretation. Aust Dent J 2012;57(Suppl 1):46-60. [CrossRef]

2. Scarfe WC, Farman AG. What is cone-beam CT and how does it work? Dent Clin North Am 2008;52(4):707-30. [CrossRef]

3. Pauwels R, Silkosessak O, Jacobs R, Bogaerts R, Bosmans $H$, Panmekiate $S$. A pragmatic approach to determine the optimal $k V p$ in cone beam CT: balancing contrast-to-noise ratio and radiation dose. Dentomaxillofac Radiol 2014;43(5):20140059. [CrossRef]

4. Panjnoush M, Kheirandish Y, Kashani PM, Fakhar HB, Younesi F, Mallahi M. Effect of Exposure Parameters on Metal Artifacts in Cone Beam Computed Tomography. J Dent (Tehran) 2016;13(3):143-50.

5. Kim MS, Kim BY, Choi HY, Choi YJ, Oh SH, Kang JH, et al. Intravenous contrast media application using cone-beam computed tomography in a rabbit model. Imaging Sci Dent 2015;45(1):31-9. [CrossRef]

6. Queiroz PM, Oliveira ML, Groppo FC, Haiter-Neto F, Freitas DQ. Evaluation of metal artefact reduction in cone-beam computed tomography images of different dental materials. Clin Oral Investig 2018;22(1):419-23. [CrossRef]

7. Taylor C. Evaluation of the effects of positioning and configuration on contrast-to-noise ratio in the quality control of a 3D Accuitomo 170 dental CBCT system. Dentomaxillofac Radiol 2016;45(5):20150430. [CrossRef]

8. Cebe F, Aktan AM, Ozsevik AS, Ciftci ME, Surmelioglu HD. The effects of different restorative materials on the detection of approximal caries in cone-beam computed tomography scans with and without metal artifact reduction mode. Oral Surg Oral Med Oral Pathol Oral Radiol 2017;123(3):392-400. [CrossRef]

9. Demirturk Kocasarac $H$, Helvacioglu Yigit D, Bechara B, Sinanoglu A, Noujeim M. Contrast-to-noise ratio with different settings in a CBCT machine in presence of different root-end filling materials: an in vitro study. Dentomaxillofac Radiol 2016;45(5):20160012. [CrossRef]

10. Barrett JF, Keat N. Artifacts in $\mathrm{CT}$ : recognition and avoidance. Radiographics 2004;24(6):1679-91. [CrossRef]

11. Wang L, D'Alpino PH, Lopes LG, Pereira JC. Mechanical properties of dental restorative materials: relative contribution of laboratory tests. J Appl Oral Sci 2003;11(3):162-7. [CrossRef]

12. Bechara B, Alex McMahan C, Moore WS, Noujeim M, Teixeira FB, Geha H. Cone beam CT scans with and without artefact reduction in root fracture detection of endodontically treated teeth. Dentomaxillofac Radiol 2013;42(5):20120245. [CrossRef]

13. Kuusisto N, Vallittu PK, Lassila LV, Huumonen S. Evaluation of intensity of artefacts in CBCT by radio-opacity of composite simulation models of implants in vitro. Dentomaxillofac Radiol 2015;44(2):20120245. [CrossRef]

14. Hwang JJ, Park H, Jeong HG, Han SS. Change in Image Quality According to the 3D Locations of a CBCT Phantom. PLoS One 2016;11(4):0153884. [CrossRef]

15. Kalender WA, Deak P, Kellermeier M, van Straten M, Vollmar SV. Application- and patient size-dependent optimization of $\mathrm{x}$-ray spectra for CT. Med Phys 2009;36(3):993-1007. [CrossRef] 
16. Bechara B, McMahan CA, Moore WS, Noujeim M, Geha $H$, Teixeira FB. Contrast-to-noise ratio difference in small field of view cone beam computed tomography machines. J Oral Sci 2012;54(3):227-32. [CrossRef]

17. Bechara B, McMahan CA, Geha H, Noujeim M. Evaluation of a cone beam CT artefact reduction algorithm. Dentomaxillofac Radiol 2012;41(5):422-8. [CrossRef]

18. Kamburoglu K, Kolsuz E, Murat S, Eren H, Yuksel S, Paksoy CS. Assessment of buccal marginal alveolar peri-implant and periodontal defects using a cone beam CT system with and without the application of metal artefact reduction mode. Dentomaxillofac Radiol 2013;42(8):20130176. [CrossRef]
19. Parsa A, Ibrahim N, Hassan B, Syriopoulos K, van der Stelt $P$. Assessment of metal artefact reduction around dental titanium implants in cone beam CT. Dentomaxillofac Radiol 2014;43(7):20140019. [CrossRef]

20. Pauwels R, Seynaeve L, Bosmans H, Bogaerts R, Jacobs R. Technical versus diagnostic image quality in dental CBCT imaging. 2013. 